\title{
Impact of Salinity Stress on Proline Reaction, Peroxide Activity, and Antioxidant Enzymes in Maize (Zea mays L.)
}

\author{
Davar Molazem*, Ali Bashirzadeh \\ Department of Agriculture Astara Branch, Islamic Azad University, Astara, Iran
}

Received: 29 June 2014

Accepted: 3 September 2014

\begin{abstract}
Salinity is one of the environmental limiting factors in agricultural production. For the aim of investigating the effects of salt stress on some physiological traits in eight varieties, including K3615/1, S.C704, B73, S.C302, Waxy, K3545/6, K3653/2, and Zaqatala in three salinity levels, Zero (control), 50, and $100 \mathrm{mM} \mathrm{NaCl}$ in three replicates for the factorial experiment was carried out in randomized complete block design. Treatments were planted in pots. During the experiment superoxide dismutase (SOD), catalase (CAT), peroxidase (POD), chlorophyll $a$, chlorophyll $b$, LRWC, and proline were measured. Increasing salinity to $50 \mathrm{mM}$ and $100 \mathrm{mM}$ increased SOD in most varieties. Maximum SOD in $50 \mathrm{mM}$ was seen in K3545/6 with 20.62 unit/min $\mathrm{g}$ fw, that with SC302 and B73 were no significant differences, but with other varieties had significant differences. In concentrations of $100 \mathrm{mM}$, there was no significant difference between varieties in ascorbate peroxidase (APX) enzyme. In these conditions maximum and minimum amount of (APX) was seen in Sc704 with 8.533 unit/min $\mathrm{g}$ fw and K3615.1 with 3.898 unit/min $\mathrm{g}$ fw, respectively. In concentrations of 100 $\mathrm{mM}$, there was a significant difference between varieties in (CAT) enzyme. In these conditions maximum and minimum amounts of (CAT) were seen in Sc302 and Sc704, respectively. Between catalase with SOD (0.234) and proline (0.284) we found positive and significant correlation at the $5 \%$ level. Significant positive correlation between proline with ascorbate peroxidase, catalase, and superoxide dismutase were observed.
\end{abstract}

Keywords: antioxidant, salt stress, Zea mays, proline

\section{Introduction}

Maize (Zea mays L.) is one of the most important crops both for human and animal consumption. This crop is cultivated on more than 142 million ha of land worldwide and it is estimated to produce around 913 million tons of grain in 2012/13 [1], accounting for one third of total global grain production [2]. In the current global climate change scenario one expected threat is the increase in land salinization [3]. Over $6 \%$ of the world's land is affected by salinity and its extent is increasing regularly throughout the world [4].

*e-mail: d.molazem@iau-astara.ac.ir
Nowadays, high salinity in soils is a very serious problem for crop production because most of the cultivated plants are sensitive to salt stress (glycophytes) [5]. Thus land salinization is a major global issue because of its adverse impact on agricultural productivity and sustainability, and as a threat to the food supply. In arid and semiarid regions, the issue is aggravated due to poor soil management practices together with limited rainfall, high evapotranspiration, and high temperature [6].

One of the common responses to different environmental stresses, both abiotic and biotic, is the accelerated generation of reactive oxygen species (ROS), including superoxide $\left(\mathrm{O}_{2}^{--}\right)$, perhydroxy radical $\left(\mathrm{HO}_{2}^{-}\right)$, hydrogen 
Table 1. Chemical and physical characteristics of the experimented pot soil.

\begin{tabular}{|c|c|c|c|c|c|c|c|c|c|c|c|c|}
\hline$\%$ Pwp & $\% \mathrm{FC}$ & $\%$ Silt & $\%$ Sand & $\%$ Clay & $\begin{array}{l}\text { Potassium } \\
\text { ppm }\end{array}$ & $\begin{array}{c}\text { Phosphorus } \\
\text { ppm }\end{array}$ & $\begin{array}{c}\% \\
\text { Organic } \\
\text { carbon }\end{array}$ & $\begin{array}{c}\% \\
\text { Organic } \\
\text { carbon }\end{array}$ & $\begin{array}{l}\% \text { of } \\
\text { neutral } \\
\text { respon- } \\
\text { dends }\end{array}$ & $\begin{array}{l}\text { The total } \\
\text { acidicy } \\
\text { of satu- } \\
\text { rated }\end{array}$ & $\begin{array}{c}\text { Ec } \\
\text { Mmols/ } \\
\mathrm{cm}\end{array}$ & $\% \mathrm{SP}$ \\
\hline 18 & 30 & 36 & 15 & 49 & 453 & 9.3 & 0.091 & 0.86 & 13.3 & 7.8 & 0.52 & 46 \\
\hline
\end{tabular}

peroxide $\left(\mathrm{H}_{2} \mathrm{O}_{2}\right)$, hydroxyl radical $\left(\mathrm{OH}^{\circ}\right)$, alkoxy radical $(\mathrm{RO})$, peroxy radical (ROO), singlet oxygen $\left(\mathrm{O}_{2}\right)$, organic hydroperoxide $(\mathrm{ROOH})$, and so forth [7-10]. Accumulation of ROS imposes ultimately oxidative stress, exacerbating cellular damage $[9,11]$.

Thus, plants need to have appropriate detoxification systems to allow rapid removal of these compounds. They constantly sense the level of ROS and reprogram their gene expression to respond to changes in their environment [12]. The most common mechanism to detoxify ROS produced during salt stress response is the induction of ROS-scavenging enzymes, such as superoxide dismutase (SOD) and catalase (CAT) [9]. SOD converts $\mathrm{O}_{2}{ }^{-}$to $\mathrm{H}_{2} \mathrm{O}_{2}$ and then CAT converts $\mathrm{H}_{2} \mathrm{O}_{2}$ to water and molecular oxygen in peroxisomes. A correlation between antioxidant capacity and $\mathrm{NaCl}$ tolerance has been demonstrated in several plant species [13]. Despite the several mechanisms developed by plants to detoxify the excess of ROS production, most of the cultivated plants are glycophytes, and under high salinity in the soil they cannot cope with the extra production of ROS [5].

\section{Materials and Methods}

Our study began in spring 2010 in a region of Ardabil branch Islamic Azad university near Hassan Baroagh village (geographical coordinates 48 and 30 of east length and 38 and 15 of north width with a height of $1,350 \mathrm{~m}$ a.s.l.). The climate of this region is cold and semidry. It has a long dry season, especially in summer. The soil of the region is clay that is poor with respect to organic material. For the purpose of investigating all factors, the analysis of soil was conducted to determine the limiting factors of growth in pot and to be sure that there isn't any primary limit in EC (Table 1).

Eight cultivars of maize, including K3615/1, S.C704, B73, S.C302, Waxy, K3545/6, K3653/2, and Zaqatala on zero salinity level (control), 50, 100, and $150 \mathrm{mM}$ of chloride sodium were cultivated on pot coincidently of the form of factorial test on 3 replications. For the aim of growth limiting factors determination, the percent of its juice was determined and the amount of the needed salt to reach to investigate salinity was calculated using saltcalc software. To do the test we used plastic pots, all of which were filled with leaf soil and sandy soil and fertilizer and cultivated soil by the ratio of 3:2:2:1. The bottoms of the pots were pierced for drainge, and a thin layer of clay was used. To avoid decreasing salt content all pots were placed in another container simultaneously with doing the cultivated salinity. The cultivation was done on 3.5.2010. Irrigation was conducted in normal environmental conditions. Among the growth period, handle weeding was conducted to avoid the growth of loose grasses. We used fertilizers twice in this period considering the feeding needs of the plants in pot condition, in all pots.

During the experiment, leaf relative water content (LRWC), superoxide dismutase (SOD), catalase (CAT), and ascorbate peroxidase (APX) and proline were measured.

For determination of antioxidant enzyme activities, fresh leaf samples $(0.3 \mathrm{~g})$ from control and treated plants were ground with liquid nitrogen, and suspended in specific buffer and $\mathrm{pH}$ for each enzyme extraction. The homogenates were centrifuged at $14,000 \mathrm{rpm}$ for $20 \mathrm{~min}$. at $4^{\circ} \mathrm{C}$ and resulting supernatants were used for enzyme assay. Superoxide dismutase (SOD) activity was determined based on the inhibition of education of nitro-blue tetrazolium in the presence of riboflavin in the light at $560 \mathrm{~nm}$ as described by Giannopolitis and Ries [14]. A unit of SOD activity is defined as the amount of enzyme, which caused $50 \%$ inhibition of the reaction in the absence of enzyme. Catalase activity was measured titrimetrically by the Chance and Maehly method [15], whereas peroxidase activity was measured on a colorimeter using purpurogallin for standard curve. The activity of APX was assayed according to Chen and Asada method [16]. The reaction mixture $(3 \mathrm{~mL})$ contained $50 \mathrm{mM}$ phosphate buffer $(\mathrm{pH}$ 7.0), $0.5 \mathrm{mM}$ ascorbic acid, $0.5 \mathrm{mM} \mathrm{H} \mathrm{H}_{2}$, and $0.1 \mathrm{~mL}$ enzyme extract. The reaction was started by the addition of $\mathrm{H}_{2} \mathrm{O}_{2}$. The activity of enzyme was assayed by measuring the decrease in absorbance at $290 \mathrm{~nm}$ for $1 \mathrm{~min}$ of ascorbic as ascorbic acid oxidized.

Photosynthetic pigments (chlorophyll $a$ and $b$ ) were measured using the method of Arnon [17] and Ashraf [18] in fresh leaf samples, a week before the harvest. One plant per replicate was used for chlorophyll determination. Prior to extraction, fresh leaf samples were cleaned with deionized water to remove any surface contamination. Leaf samples $(0.5 \mathrm{~g})$ were homogenized with acetone $(80 \% \mathrm{v} / \mathrm{v})$, filtered, and made up to a final volume of $5 \mathrm{ml}$. Then the solution for 10 minutes away in 3,000 (rpm) centrifuged. Pigment concentrations were calculated from the absorbance of extract at 663 and $645 \mathrm{~nm}$ using the formula given below:

a) Chlorophyll $a(\mathrm{mg} / \mathrm{g} \mathrm{FW})=[12.7 \times(\mathrm{A} 663)-2.69 \times$ $(\mathrm{A} 645)] \times 0.5$

b) Chlorophyll $b(\mathrm{mg} / \mathrm{g} \mathrm{FW})=[22.9 \times(\mathrm{A} 645)-4.69 \times$ (A663) $] \times 0.5$

c) Chlorophyll $a+b(\mathrm{mg} / \mathrm{g} \mathrm{FW})=[20.2 \times(\mathrm{A} 645)-8.02 \times$ $(\mathrm{A} 663)] \times 0.5$ 
Table 2. Analysis of variance of understudy characteristics in eight cultivars of maize.

\begin{tabular}{|c|c|c|c|c|c|c|c|c|}
\hline \multirow{2}{*}{ SOV } & \multirow{2}{*}{ DF } & \multicolumn{7}{|c|}{ Mean Square } \\
\cline { 3 - 10 } & & Chlorophyll $a$ & LRWC & Chlorophyll $b$ & Catalaz & $\begin{array}{c}\text { Ascorbate } \\
\text { peroxidase }\end{array}$ & Proline & $\begin{array}{c}\text { Superoxide } \\
\text { dismutase }\end{array}$ \\
\hline Replication & 2 & $0.001 \mathrm{~ns}$ & $471.911 \mathrm{~ns}$ & $0.001 \mathrm{~ns}$ & $5.492^{*}$ & $0.191 \mathrm{~ns}$ & $31.179 \mathrm{~ns}$ & $3.281 \mathrm{~ns}$ \\
\hline Salinity & 2 & $0.007^{* *}$ & $3054.333^{* *}$ & $0.002^{*}$ & $0.122 \mathrm{~ns}$ & $1.264^{* *}$ & $2.356 \mathrm{~ns}$ & $2.328^{* *}$ \\
\hline Genotype & 7 & $0.001 *$ & $3186.795^{* *}$ & $0.0001 \mathrm{~ns}$ & $4.988^{* *}$ & $0.591^{* *}$ & $95.916^{* *}$ & $1.559^{* *}$ \\
\hline Salt×Genotype & 14 & $0.0001 \mathrm{~ns}$ & $865.230^{* *}$ & $0.001 \mathrm{~ns}$ & $1.436 \mathrm{~ns}$ & $0.198 \mathrm{~ns}$ & $70.857^{* *}$ & $0.479 \mathrm{~ns}$ \\
\hline Error & 46 & 0.0001 & 293.617 & 0.001 & 1.572 & 0.137 & 22.279 & 0.485 \\
\hline$\%$ CV & & 0.35 & 23.89 & 1.26 & 20.04 & 6.43 & 25.20 & 11.79 \\
\hline
\end{tabular}

* Significant difference in probability level of $5 \%$, ** significant difference in probability level of $1 \%$

Free proline accumulation was determined using the method of Bates et al. [19]. 0.04 gram dry weight of leaves was homogenized with $3 \%$ sulfosalicylic acid and after 72 $\mathrm{h}$ that proline was released; the homogenate was centrifuged at 3,000 g for $20 \mathrm{~min}$. The supernatant was treated with acetic and acid ninhydrin, boiled for 1 hour, and then absorbance at $520 \mathrm{~nm}$ was determined by a Uv-visible spectrophotometer.

Leaf relative water content (LRWC) was calculated on the basis of the Yamasaki and Dillenburg method [20]. Two leaves were randomly chosen from middle parts of the plants in each repetition. At first, leaves were separated from the stems and their fresh masses (FM) were calculated. In order to measure the saturation mass (TM), they were placed into the distilled water in closed containers for 24 hours at $22^{\circ} \mathrm{C}$ for the purpose of reaching their greatest amount of saturation mass, and then they were weighed. Then leaves were placed inside the electrical oven for 48 hours under at of $80^{\circ} \mathrm{C}$ and the dry mass of the leaves (DM) was obtained (DM). All of the measurements were done by scales with $0.001 \mathrm{~g}$ accuracy and were placed into the following formula:

$$
\operatorname{LRWC}(\%)=[(\mathrm{FM}-\mathrm{DM}) /(\mathrm{TM}-\mathrm{DM})] \times 100
$$

Statistical analysis of the data was done on the basis of randomized complete block design. The average of attendances was calculated on the basis of Duncan method at $5 \%$ probability level.

\section{Result and Discussion}

Analysis of variance for the studied traits are shown in Table 2. For the traits ascorbate peroxidase, superoxide dismutase, chlorophyll $a$, chlorophyll $b$, and LRWC at different levels of salinity were a significant difference. Azooz et al. [21] in the activity of antioxidant enzymes in maize Cultivar showed that in the control (no salt) with salinity levels significant differences was seen [21]. Drought and salinity stresses are two of the most important environmental factors limiting plant growth and productivity worldwide [22]. The tolerance to salinity or water stress could be related to different genetically determined capacity of plants to cope with oxidative stress events [23]. Therefore, the identification of physiological and biochemical components of the antioxidative defense system, which have the potential to confer drought or salinity tolerance, could be essential for the characterization of stress-tolerant plant species [24].
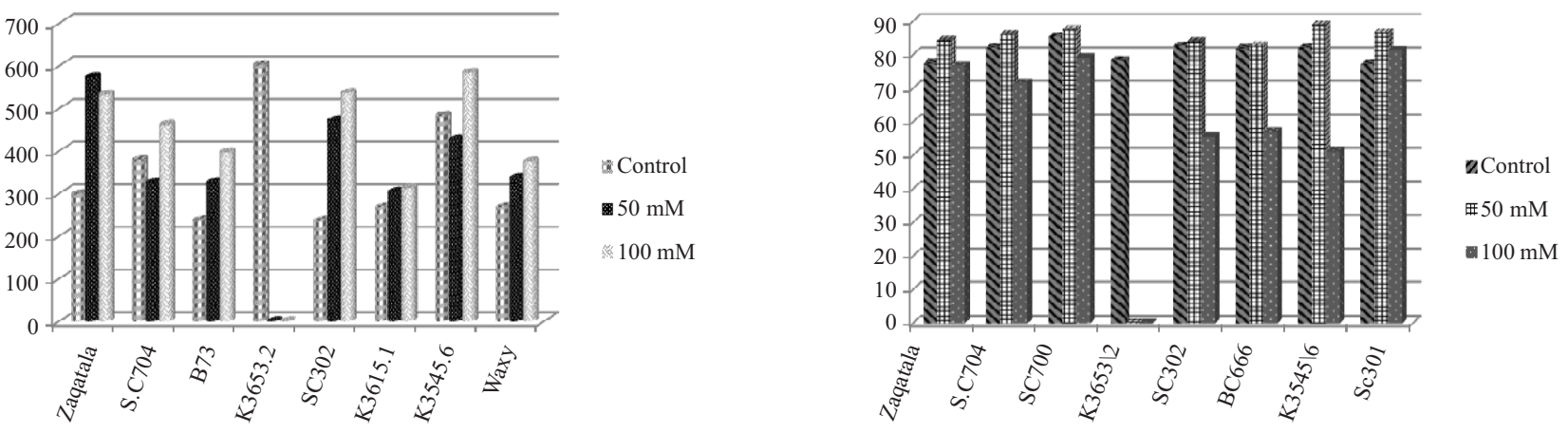

Fig. 1. Diagram of physiological characteristics in eight cultivars of the maize under salinity. 
Activities of both CAT and SOD showed dramatic increases in plants under moderate salt stress $(150 \mathrm{mM} \mathrm{NaCl})$ compared with control, similar to findings by Barakat [25].

Between the varieties for catalase enzyme, chlorophyll $a$, LRWC, ascorbate peroxidase, superoxide dismutase, and proline, significant difference was seen in $1 \%$ probability level, but there was significant difference in interaction between varieties in salinity for only proline and LRWC. In enzyme ascorbate peroxidase, significant differences were obtained between varieties at the $1 \%$ level. But there was no significant interaction between varieties in salinity. In enzyme superoxide dismutase, significant differences were obtained between varieties at the $1 \%$ level. But there was no significant interaction between varieties in salinity.

Comparing the average of understudy characteristics are shown in Table 3. In the control condition, there was no significant difference between varieties in superoxide dismutase enzyme. In these conditions maximum and minimum amounts of SOD were seen in Sc302 and Sc704, respectively. With increasing salinity to $50 \mathrm{mM}$ and 100 $\mathrm{mM}$, increased SOD in most varieties (Fig. 1). Tuna et al. [26] in effect of gibberellic acid and salinity on antioxidants and growth parameters on corn plant showed that with increasing salt concentration, a significant decrease in dry weight, relative amount of chlorophyll, and leaf water content was seen.

Maximum of SOD in $50 \mathrm{mM}$, was seen in K3545/6 with 20.62 unit/min $\mathrm{g}$ fw, that with SC302 and B73 were no significant differences, but with other varieties had significant differences. In this condition a minimum amount of SOD was seen in Sc704 with 4.318 unit/min $\mathrm{g}$ fw. Koca et al. [27] and Athar et al. [28] showed that superoxide dismutase activity in resistant varieties to salinity increases sharply.

In concentration of $100 \mathrm{mM}$ salt, maximum of SOD was seen in Zaqatala with 26.45 unit/min $\mathrm{g}$ fw, that with Waxy and B73 there were no significant differences, but other varieties had significant differences. In this condition a minimum amount of SOD was seen in K3615.1 with $7.971 \mathrm{unit} / \mathrm{min} \mathrm{g}$ fw. In the control condition, there was a significant difference between varieties in ascorbate peroxidase (APX) enzyme. In these conditions maximum amount of ascorbate peroxidase (APX) enzyme was seen in Sc302, which did not show a significant difference with Waxy. Minimum (APX) were measured in B73. In concentration of $50 \mathrm{mM}$, maximum amount of ascorbate peroxidase (APX) in sc302 was obtained, that with the other varieties saw a significant difference. Varieties $\mathrm{k} 3653 \backslash 2$ in 50 $\mathrm{mM}$ salt was removed. In concentration of $100 \mathrm{mM}$, there was no significant difference between varieties in ascorbate peroxidase (APX) enzyme. In these conditions maximum and minimum amounts of (APX) were seen in Sc704 with 8.533 unit/min $\mathrm{g} \mathrm{fw}$ and K3615.1 with $3.898 \mathrm{unit} / \mathrm{min} \mathrm{g}$ fw (Fig. 2).

In the control condition there was a significant difference between varieties in catalase (CAT) enzyme. In these conditions maximum amount of catalase (CAT) enzyme was seen in K3615.1 with 43.33 unit/min $\mathrm{g} \mathrm{fw}$, which did not show a significant difference with Waxy with 35.22 unit/min $\mathrm{g}$ fw. Minimum (CAT) were measured in K365312 with 2.493. In concentrations of $50 \mathrm{mM}$, maximum amount
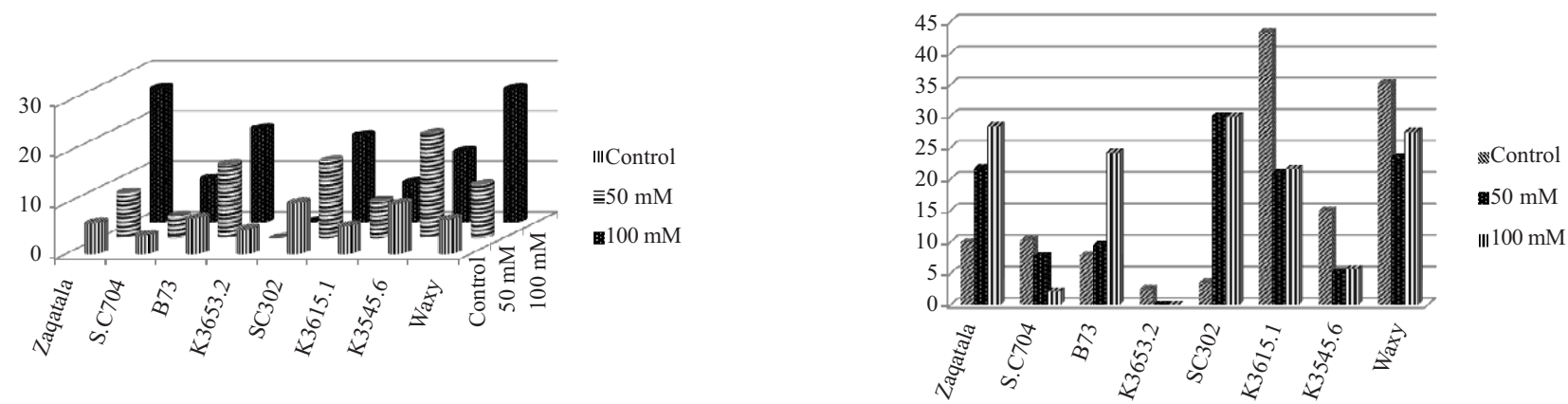

Ascorbate peroxidase Unit/min $\mathrm{g}$ fw

Chlorophyll $a \mathrm{mg} / \mathrm{g}$ fw

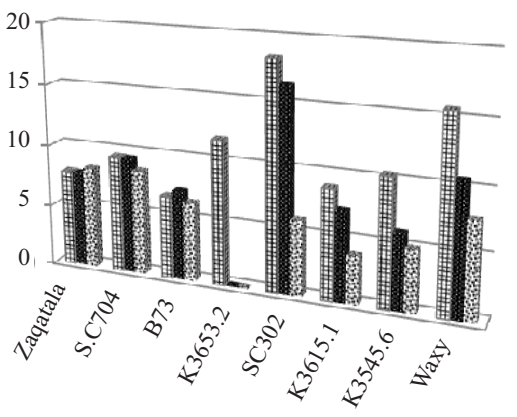

田Control

$\$ 50 \mathrm{mM}$

$100 \mathrm{mM}$

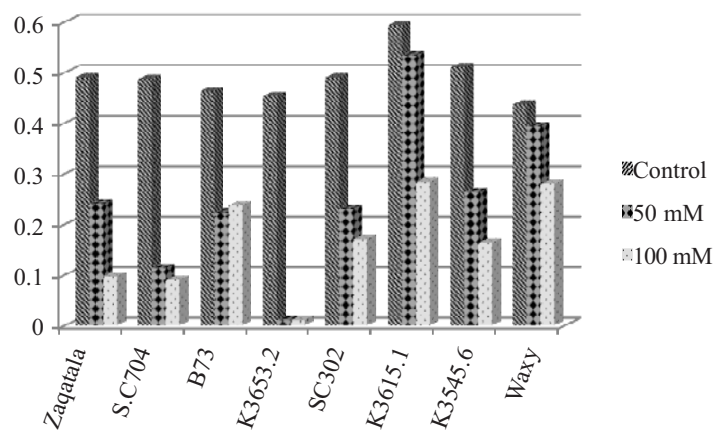

Fig. 2. Diagram of physiological characteristics in eight cultivars of the maize under salinity. 
Table 3. Comparing the averages of understudy characteristics in eight cultivars of maize.

\begin{tabular}{|c|c|c|c|c|c|c|c|c|c|c|c|c|c|c|c|}
\hline Salinity & Cultivar & $\begin{array}{r}\text { Chloropl } \\
\mathrm{mg} / \mathrm{gf}\end{array}$ & $\begin{array}{l}\text { yll } b \\
\text { w }\end{array}$ & $\begin{array}{r}\text { LRV } \\
\%\end{array}$ & & $\begin{array}{r}\text { Chloro } \\
\mathrm{mg} /\end{array}$ & $\begin{array}{l}\text { yll } a \\
\text { W }\end{array}$ & $\begin{array}{r}\text { Super } \\
\text { dism } \\
\text { Unit/m }\end{array}$ & $\begin{array}{l}\text { zide } \\
\text { ase } \\
g \text { fw }\end{array}$ & $\begin{array}{r}\text { Prol } \\
\mu \mathrm{mol}\end{array}$ & & $\begin{array}{l}\text { Ascor } \\
\text { peroxi } \\
\text { Unit/mi }\end{array}$ & & $\begin{array}{r}\text { Cata } \\
\text { Unit/m }\end{array}$ & $\begin{array}{l}\mathrm{se} \\
\mathrm{q} \mathrm{fw}\end{array}$ \\
\hline \multirow{8}{*}{ Control } & Zaqatala & 0.1933 & $\mathrm{a}$ & 77.51 & $\mathrm{a}$ & 0.4900 & $\mathrm{a}$ & 6.044 & $\mathrm{a}$ & 298.9 & & 7.794 & & 9.963 & $\mathrm{~b}$ \\
\hline & Sc704 & 0.3100 & $\mathrm{a}$ & 82.21 & $\mathrm{a}$ & 0.4867 & $\mathrm{a}$ & 3.701 & $\mathrm{a}$ & 378.5 & $\mathrm{bc}$ & 9.464 & & 10.32 & $\mathrm{~b}$ \\
\hline & B73 & 0.1833 & $\mathrm{a}$ & 85.41 & $\mathrm{a}$ & 0.4633 & $\mathrm{a}$ & 7.021 & $\mathrm{a}$ & 237.3 & $\mathrm{c}$ & 6.681 & $\mathrm{~d}$ & 7.833 & $\mathrm{~b}$ \\
\hline & K36532 & 0.2800 & $\mathrm{a}$ & 78.43 & $\mathrm{a}$ & 0.4533 & $\mathrm{a}$ & 4.858 & $\mathrm{a}$ & 602.0 & $\mathrm{a}$ & 11.69 & $\mathrm{bc}$ & 2.493 & $\mathrm{~b}$ \\
\hline & Sc302 & 0.1667 & $\mathrm{a}$ & 82.72 & $\mathrm{a}$ & 0.4900 & $\mathrm{a}$ & 10.06 & $\mathrm{a}$ & 236.4 & $\mathrm{c}$ & 18.37 & $\mathrm{a}$ & 3.560 & $\mathrm{~b}$ \\
\hline & K3615.1 & 0.3733 & $\mathrm{a}$ & 81.92 & $\mathrm{a}$ & 0.5933 & $\mathrm{a}$ & 5.494 & $\mathrm{a}$ & 268.1 & $\mathrm{c}$ & 8.908 & $\mathrm{~cd}$ & 43.33 & $\mathrm{a}$ \\
\hline & K35456 & 0.3800 & $\mathrm{a}$ & 82.06 & $\mathrm{a}$ & 0.5100 & $\mathrm{a}$ & 9.914 & $\mathrm{a}$ & 482.9 & $\mathrm{ab}$ & 10.35 & $\mathrm{~cd}$ & 14.95 & $\mathrm{~b}$ \\
\hline & Waxy & 0.4167 & $\mathrm{a}$ & 77.30 & $\mathrm{a}$ & 0.4367 & $\mathrm{a}$ & 6.801 & $\mathrm{a}$ & 268.5 & $\mathrm{c}$ & 15.59 & $a b$ & 35.22 & $\mathrm{a}$ \\
\hline \multirow{8}{*}{$50 \mathrm{mM}$} & Zaqatala & 0.3233 & $a b c$ & 84.36 & $\mathrm{a}$ & 0.2400 & $\mathrm{bc}$ & 8.971 & bcd & 574.0 & $\mathrm{a}$ & 7.794 & $\mathrm{~b}$ & 21.70 & $a b$ \\
\hline & Sc704 & 0.5167 & $\mathrm{a}$ & 86.07 & $\mathrm{a}$ & 0.1133 & $\mathrm{~cd}$ & 4.318 & $\mathrm{~cd}$ & 325.1 & $\mathrm{~b}$ & 9.464 & b & 7.750 & $\mathrm{bc}$ \\
\hline & B73 & 0.2233 & bcd & 87.55 & $\mathrm{a}$ & 0.2233 & $\mathrm{bc}$ & 14.59 & $\mathrm{ab}$ & 325.6 & $\mathrm{~b}$ & 7.238 & $\mathrm{~b}$ & 9.480 & $\mathrm{bc}$ \\
\hline & K36532 & 0.0000 & $\mathrm{E}$ & 0.000 & $\mathrm{~b}$ & 0.010 & $\mathrm{e}$ & 0.000 & $\mathrm{e}$ & 0.000 & $\mathrm{c}$ & 0.000 & $\mathrm{c}$ & 0.00 & $\mathrm{~d}$ \\
\hline & Sc302 & 0.3833 & $a b$ & 84.01 & $\mathrm{a}$ & 0.2300 & $\mathrm{bc}$ & 15.28 & $\mathrm{ab}$ & 471.8 & $\mathrm{ab}$ & 16.42 & $\mathrm{a}$ & 30.07 & $\mathrm{a}$ \\
\hline & K3615.1 & 0.2867 & $a b c$ & 82.78 & $\mathrm{a}$ & 0.5333 & $\mathrm{a}$ & 7.384 & bcd & 304.4 & $\mathrm{~b}$ & 7.294 & $\mathrm{~b}$ & 20.88 & $a b$ \\
\hline & K35456 & 0.1867 & bcd & 88.97 & $\mathrm{a}$ & 0.2633 & $\mathrm{bc}$ & 20.62 & $\mathrm{a}$ & 426.8 & $\mathrm{ab}$ & 6.124 & $\mathrm{~b}$ & 5.250 & $\mathrm{bc}$ \\
\hline & Waxy & 0.09333 & $\mathrm{~cd}$ & 86.82 & $\mathrm{a}$ & 0.3933 & $a b$ & 10.61 & $\mathrm{bc}$ & 337.1 & $\mathrm{~b}$ & 10.60 & $\mathrm{~b}$ & 23.48 & $\mathrm{ab}$ \\
\hline \multirow{8}{*}{$\begin{array}{l}100 \\
\mathrm{mM}\end{array}$} & Zaqatala & 0.1367 & $a b$ & 76.79 & $\mathrm{a}$ & 0.0966 & $a b c$ & 26.45 & $\mathrm{a}$ & 533.1 & $\mathrm{ab}$ & 8.258 & $\mathrm{a}$ & 28.46 & $\mathrm{a}$ \\
\hline & Sc704 & 0.02333 & $\mathrm{~b}$ & 71.72 & $a b$ & 0.0900 & $\mathrm{bc}$ & 8.641 & cde & 461.7 & $a b c$ & 8.533 & $\mathrm{a}$ & 2.123 & $\mathrm{c}$ \\
\hline & B73 & 0.1467 & $a b$ & 79.28 & $\mathrm{a}$ & 0.2367 & $a b$ & 18.59 & $a b$ & 397.3 & $\mathrm{bc}$ & 6.404 & $\mathrm{a}$ & 24.19 & $\mathrm{a}$ \\
\hline & K36532 & 0.0000 & $\mathrm{c}$ & 0.000 & $\mathrm{~d}$ & 0.0100 & $d$ & 0.000 & $\mathrm{f}$ & 0.000 & $\mathrm{~d}$ & 0.000 & $\mathrm{c}$ & 0.000 & $\mathrm{~d}$ \\
\hline & Sc302 & 0.03333 & $\mathrm{~b}$ & 55.56 & $\mathrm{bc}$ & 0.1700 & $a b c$ & 17.20 & $\mathrm{bc}$ & 537.0 & $\mathrm{ab}$ & 6.124 & $\mathrm{a}$ & 29.93 & $\mathrm{a}$ \\
\hline & K3615.1 & 0.1733 & $\mathrm{ab}$ & 57.10 & $\mathrm{bc}$ & 0.2833 & $\mathrm{a}$ & 7.971 & de & 312.6 & $\mathrm{c}$ & 3.898 & $a b$ & 21.60 & $\mathrm{ab}$ \\
\hline & K35456 & 0.02000 & $\mathrm{~b}$ & 51.31 & $\mathrm{c}$ & 0.1633 & $a b c$ & 14.00 & bcd & 584.4 & $\mathrm{a}$ & 5.011 & $\mathrm{a}$ & 5.650 & $\mathrm{bc}$ \\
\hline & Waxy & 0.2967 & $\mathrm{a}$ & 81.39 & $\mathrm{a}$ & 0.2800 & $\mathrm{a}$ & 26.37 & $\mathrm{a}$ & 375.4 & $\mathrm{bc}$ & 7.794 & $\mathrm{a}$ & 27.52 & $\mathrm{a}$ \\
\hline
\end{tabular}

* significant difference in probability level of $5 \%$, ** significant difference in probability level of $1 \%$

of (CAT) in sc302 was obtained, which did not show a significant difference with Zaqatala, K3615.1, and Waxy. In concentrations of $100 \mathrm{mM}$, there was a significant difference between varieties in (CAT) enzyme. In these conditions maximum and minimum amounts of (CAT) were seen in Sc302 and Sc704, respectively. In normal conditions, between variety, in terms of chlorophyll $a$, chlorophyll $b$, and leaf relative water content was not significantly different. Reduced chlorophyll content during stress recorded under the present investigation confirmed the harmful effects of ROS on photosynthetic pigments and ultimately on photosynthesis. This is in line with results reported in sunflower [29], rice [30], bean [31], maize [32], and wheat [33]. In normal conditions the maximum proline content in K3653.2 obtained with K3545.6 showed no significant difference. Proline content increased significantly under drought and severe salt stress conditions in A. altissima seedlings, supporting its role as a protective agent under oxidative stress conditions [34].

Simple correlation between antioxidant enzyme and some growth characteristics shown in Table 4. Between catalase with SOD (0.234) and proline (0.284) we found positive and significant correlation at the 5\% level. Significant positive correlation between proline with ascorbate peroxidase, catalase, and superoxide dismutase were observed. Between leaf relative water content with antioxidant enzymes and proline significant positive correlation was calculated. Between chlorophyll with ascorbate peroxidase and leaf relative water content, a significant positive correlation was computed. Significant positive correlation between ascorbate peroxidase, with leaf relative water content, proline, and chlorophyll $a$ and $b$ were calculated. Although these correla- 
Table 4. Simple correlation between antioxidant enzyme and some growth characteristics in eight maize cultivars.

\begin{tabular}{|l|c|c|c|c|c|c|c|}
\hline & Catalase & APX & SOD & Proline & LRWC & Chl. $a$ & Chl. $b$ \\
\hline Catalase & 1 & 0.098 & $0.234^{*}$ & $0.284^{*}$ & $0.313^{* *}$ & 0.167 & 0.098 \\
\hline APX & & 1 & 0.058 & $0.352^{* *}$ & $0.551^{* *}$ & $0.433^{* *}$ & $0.292^{*}$ \\
\hline SOD & & & 1 & $0.427^{* *}$ & $0.372^{* *}$ & 0.062 & -0.097 \\
\hline Proline & & & & 1 & $0.632^{* *}$ & 0.168 & 0.118 \\
\hline LRWC & & & & & 1 & $0.491^{* *}$ & $0.347^{* *}$ \\
\hline Chlorophyll $a$ & & & & & & 1 & 0.170 \\
\hline Chlorophyll $b$ & & & & & & & 1 \\
\hline
\end{tabular}

*Correlation is significant at the 0.05 level, ${ }^{* *}$ Correlation is significant at the 0.01 level

tions between pigment content and antioxidant capacity were higher than those reported by Zilic et al. [35], these authors also found that a higher content of pigments in the maize kernel contributes to their higher antioxidant capacity. Other authors have also found that dark color is associated with higher antioxidant capacity [36, 37].

\section{Abbreviations}

Ascorbate peroxidase - APX

Catalase - CAT

Nitroblue tetrazolium - NBT

Reactive oxygen species - ROS

Superoxide dismutase - SOD

Leaf relative water content - LRWC

\section{References}

1. IGC, Grain Market Report, in: IGC Grains conference 2012, International Grains Council, London, 7 June, 2012.

2. HENG .L.K. HSIAO T. EVETT S. HOWELL T. STEDUTO P. Validating the FAO AquaCrop Model for irrigated and water deficient field maize. Agron. J. 101, 488, 2009.

3. FAO. Proceedings of the Global Forum on Salinization and Climate Change (GFSCC2010), R.P. Thomas (Ed) World Soil Resources Reports, Rome, Italy. 2011.

4. SCHWABE K.A. IDDO K. KNAP K.C. Drain water management for salinity mitigation in irrigated agriculture. Am. J. Agric. Econ. 88. 133, 2006.

5. MUNNS R., TESTER M. Mechanisms of salinity tolerance. Annu. Rev. Plant Biol. 59. 651, 2008.

6. AZEVEDO NETO A.D., PRISCO J.T., ENÉAS-FILHO J.C., ABREU E.B., GOMES-FILHO E. Effect of salt stress on antioxidative enzymes and lipid peroxidation in leaves and roots of salt-tolerant and saltsensitive maize genotypes. J. Environ. Exp. Bot., 56, 87, 2006.

7. BHATTACHARJEE S. Sites of generation and physicochemical basis of formation of reactive oxygen species in plant cell. [In] Reactive Oxygen Species and Antioxidants in Higher Plants, S. Dutta Gupta, Ed., pp. 1-30, CRC Press, New York, NY, USA, 2010.

8. MILLER G., SHULAEV V., MITTLER R. Reactive oxygen signaling and abiotic stress. Physiol. Plantarum, 133, (3), 481, 2008.
9. GILL S. S., TUTEJA N. Reactive oxygen species and antioxidant machinery in abiotic stress tolerance in crop plants. Plant Physiol. Bioch. 48, 909, 2010.

10. MILLER G. SCHLAUCH K., TAM R. The plant NADPH oxidase RBOHD mediates rapid systemic signaling in response to diverse stimuli. Science Signaling, 2, (84), 45, 2009.

11. KOVALCHUK I. Multiple roles of radicles in plants. [In] Reactive Oxygen Species and Antioxidants in Higher Plants, S. Dutta Gupta, Ed., pp. 31-44, CRC Press, New York, NY, USA, 2010.

12. MILLER G. SUZUKI N. CIFTCI-YILMAZ S. MITTLER R. Reactive oxygen species homeostasis and signalling during drought and salinity stresses. Plant Cell Environ. 33, 453, 2010 .

13. TÜRKAN I., DEMIRAL T. Recent developments in understanding salinity tolerance, Environ. Exp. Bot. 67, 2, 2009.

14. GIANNOPOLITIES C.N., RIES S.K. 1977. Superoxide dismutase. I. Occurrence in higher plants. Plant Physiol., 59, 309, 2009.

15. CHANCE B., MAEHLY C. Assay of catalase and peroxidases. Methods Enzymol., 11, 764, 1955.

16. CHEN G., ASADA K. Inactivation of ascorbate peroxidase by thoils requires hydrogen peroxide. Plant Cell Physiol., 33, 117, 1992.

17. ARNON D.I. Copper enzymes in isolated chloroplasts;polyphenol-oxidase in Beta vulgaris. Plant Physiol., 24, 1, 1975.

18. ASHRAF M.Y., AZMI A.R., KHAN A.H., ALA S.A. Effect of water stress on total phenols, peroxides activity and chlorophyll content in wheat. Acta Physiology Plant, 16, (3), 1, 1994.

19. BATES L. Rapid determination of free proline for water stress studies. Plant Soil, 39, 205, 1973.

20. YAMASAKI S., DILLENBURG L.C. Measurements of leaf relative water content in Araucaria angustifolia. R. Bras. Fisiol. Veg. 11, 69, 1999.

21. AZOOZ M.M., ISMAIL A.M., ABOU ELHAMD M.F. Growth, Lipid Peroxidation and Antioxidant Enzyme Activities as a Selection Criterion for the Salt Tolerance of Maize Cultivars. International Journal of Agriculture and Biology, 11, (1), 21, 2009.

22. KRASENSKY J., JONAK C. Drought, salt, and temperature stress-inducedmetabolic rearrangements and regulatory networks. J. Exp. Bot. 63, 1593, 2012.

23. GOLLDACK D., LUKING I., YANG O. Plant tolerance to drought and salinity: stressregulating transcription factors and their functional significance in the cellulartranscriptional network. Plant Cell Rep. 30, 1383, 2011. 
24. VASEVA I., AKISCAN Y., SIMOVA-STOILOVA L., KOSTADINOVA A., NENKOVA R., ANDERS I., FELLER U., DEMIREVSKA K. Antioxidant response to drought in red andwhite clover. Acta Physiologiae Plantarum 34, 1689, 2012.

25. BARAKAT N.A.M. Oxidative stress markers and antioxidant potential of wheattreated with phytohormones under salinity stress. Journal of Stress Physiologyand Biochemistry 7, 250, 2011.

26. TUNA A., LEVENT KAYA C., HIGGS D. The combined effects of gibberellic acid and salinity on some antioxidant enzyme activities, plant growth parameters and nutritional status in maize plants. Environ. Exp. Bot. 62, (1), 1, 2008.

27. KOCA H., BOR M. ÖZDEMIR F., TÜRKAN İ. The effect of salt stress on lipid peroxidation, antioxidative enzymes and proline content of sesame cultivars. Environ. Exp. Bot., 60, 344, 2007.

28. ATHAR H., KHAN A., ASHRAF M. Exogenously applied ascorbic acid alleviates salt-induced oxidative stress in wheat. Environ. Exp. Bot., 63, 224, 2008.

29. MANIVANNAN P., JALEEL C. A., SANKAR B., KISHOREKUMAR A., SOMASUNDARAM R., ALAGULAKSHMANAN G. M. Growth, biochemical modifications and proline metabolism in Helianthus annuus L. as induced by drought stress. Colloids and Surfaces B: Biointerfaces, 59, 141, 2007.

30. PATTANAGUL W. Exogenous abscisic acid enhances sugar accumulation in rice (Oriza sativa L.) under drought stress. Asian Journal of Plant Science, 10, 212, 2011.
31. DOLATABADIAN A., JOUNEGHAN R. S. Impact of exogenous ascorbic acid on antioxidant activity and some physiological traits of common bean subjected to salinity stress. Notulae Botanicae Horti Agrobotanici Cluj, 37, 165, 2009.

32. DOLATABADIAN A., SANAVI A. M., SHARIFI M. Alleviation of water deficit stress effects by foliar application of ascorbic acid on Zea mays L. J. Agron. Crop Sci., 195, 347, 2009

33. MOAVENI P. Effect of water deficit stress on some physiological traits of wheat (Triticum aestivum). Agricultural Science Research Journal, 1, 64, 2011.

34. DE CARVALHO K., DE CAMPOS M.K.F., DOMINGUES D.S., PEREIRA L.F.P., VIEIRA L.G.E. The accumulation of endogenous proline induces changes in gene expres-sion of several antioxidant enzymes in leaves of transgenic Swingle citrumelo. Mol. Biol. Rep. 40, 3269, 2013.

35. ZILIC S., SERPEN A., AKILLIOGLU G., GOKMEN V., VANCETOVIC J. Phenolic compounds, carotenoids, anthocyanins, and antioxidant capacity of colored maize (Zea mays L.) Kernels. J Agric Food Chem 60, (5), 1224, 2012.

36. LOPEZ-MARTINEZ L.X., PARKIN K.L., GARCIA H.S Effect of processing of corn for production of masa, tortillas and tortilla chips on the scavenging capacity of reactive nitrogen species. Int J Food Sci Technol 47, (6), 1321, 2012.

37. HU Q. P., XU J. G. Profiles of carotenoids, anthocyanins, phenolics, and antioxidant capacity of selected color waxy corn grains during maturation. J Agric Food Chem 59, (5), 2026, 2011. 
